\title{
IMPLEMENTATION PROMPTNESS ANALYSIS IN MENINGOCOCCAL MENINGITIS VACCINATION IN UMRAH PILGRIMS IN SURABAYA
}

\author{
Analisis Ketepatan Waktu Pelaksanaan Vaksinasi Meningitis Meningokokus Jemaah Umroh di Surabaya
}

Putri Yuliasari $^{1}$, Pujo Suwanto ${ }^{2}$

${ }^{1}$ Public Health Faculty, putri.yuliasari-2015@fkm.unair.ac.id

${ }^{2}$ Port Health Office Class I Surabaya, pudjo70_endut@ rocketmail.com

Correspondencing Author: Putri Yuliasari, putri.yuliasari-2015@fkm.unair.ac.id, Department of Epidemiology, Public Health Faculty, Universitas Airlangga, Dr. Ir. H. Soekarno Street, Mulyorejo, Surabaya, East Java, Indonesia, Postal Code 60115

\section{ARTICLE INFO \\ Article History: \\ Received May, $5^{\text {th }}, 2019$ \\ Revised form June, $17^{\text {th }}, 2019$ \\ Accepted August, 29 , 2019 \\ Published online August, 30 ${ }^{\text {th }}, 2019$}

Keywords:
vaccination;
meningococcal meningitis;
umrah pilgrims;
port health office

\section{Kata Kunci:}

vaksinasi;

meningitis meningokokus;

jemaah umroh;

kantor kesehatan pelabuhan

\begin{abstract}
Background: Umrah pilgrims have a high potential risk of getting infected by Meningococcus Meningitis . Even though meningitis cases had never happened in Indonesia, The vaccination carried out less than 14 days in the Port Health Office Class I of Surabaya (PHO) was still found in December 2018. Purpose: The research aims to analyze the accuracy of Meningococcus Meningitis immunization in the Port Health Office Class I Surabaya (PHO) at Tanjung Perak Port Work Area in December 2018. Methods: The research was carried out in a quantitative descriptive study with a cross-sectional study design. The research samples included all Umrah pilgrims who were vaccinated with Meningococcus Meningitis immunization. The variables consisted of age, time-range of vaccination implementation, gender, and domicile/residence of respondents. The data analysis was carried out using univariate analysis and displayed in the form of a frequency table. Results: This study indicated that almost all pilgrims were vaccinated in more than or equal to 14 days (76\%). Meanwhile, the others (24\%) were vaccinated at less than 14 days, i.e., at 5-6 days before departure. The majority of pilgrims with a history of vaccinations on less than 14 days of departure were female (56.12\%) and lived in Surabaya (55.27\%). Conclusion: The majority of the pilgrims in PHO Class I of Surabaya had carried out Meningococcus Meningitis vaccination promptly. However, a small number of pilgrims did not carry out vaccinations under the specified time. Female pilgrims, mostly domiciled in Surabaya, dominated the vaccination on less than 14 days.
\end{abstract}

C2019 Jurnal Berkala Epidemiologi. Published by Universitas Airlangga. This is an open access article under CC-BY-SA license (https://creativecommons.org/licenses/by-sa/4.0/)

\section{ABSTRAK}

Latar Belakang: Jemaah umrah berrisiko tinggi terinfeksi penyakit meningitis meningokokus saat melaksanakan ibadah umrah. Kasus meningitis belum pernah terjadi di Indonesia, namun pelaksanaan vaksinasi $<14$ hari masih ditemukan di Kantor Kesehatan Pelabuhan (KKP) Kelas I Surabaya pada bulan Desember tahun 2018. Tujuan: Penelitian ini bertujuan untuk menganalisis ketepatan pelaksanaan 
vaksinasi meningitis meningokokus di KKP Kelas I Surabaya Wilayah Kerja Pelabuhan Tanjung Perak pada Desember 2018. Metode: Penelitian ini merupakan penelitian deskriptif kuantitatif dengan desain studi cross sectional. Sasaran penelitian adalah seluruh jemaah umrah yang melakukan vaksinasi meningitis meningokokus di KKP Kelas I Surabaya wilayah kerja Pelabuhan Tanjung Perak pada bulan Desember tahun 2018. Variabel yang diteliti yaitu umur, jarak pelaksanaan vaksinasi, jenis kelamin, dan domisili/tempat tinggal responden. Analisis data menggunakan analisis univariate yang ditampilkan dalam bentuk tabel frekuensi. Hasil: Penelitian ini menunjukkan bahwa hampir seluruh jemaah telah melakukan vaksinasi more than or equal to 14 hari (76\%), namun masih ditemukan pelaksanaan vaksinasi yang kurang dari 14 hari sebesar 24\% (711 jemaah) yaitu mayoritas pada 5-6 hari sebelum keberangkatan. Mayoritas jemaah dengan riwayat vaksinasi kurang dari 14 hari berjenis kelamin perempuan (56,12\%) dan berdomisili di Kota Surabaya (55,27\%). Kesimpulan: Mayoritas jemaah di KKP Kelas I Surabaya telah melaksanakan vaksinasi meningitis meningokokus dengan tepat waktu namun masih ditemukan sebagian kecil jemaah yang tidak melaksanakan vaksinasi sesuai dengan waktu yang ditentukan. Pelaksanaan vaksinasi $<14$ hari didominasi oleh jemaah berjenis kelamin perempuan dan berdomisili Surabaya.

C2019 Jurnal Berkala Epidemiologi. Penerbit Universitas Airlangga. Jurnal ini dapat diakses secara terbuka dan memiliki lisensi CC-BY-SA (https://creativecommons.org/licenses/by-sa/4.0/)

\section{INTRODUCTION}

Meningitis is a disease that occurs due to infection or inflammation on the brain-protective membrane and spinal cord system. Meningitis is a severe disease that requires an accurate and efficient way to diagnose. Various agents, such as fungi, bacteria, mycobacteria, and viruses commonly serve as the causes of infectious meningitis and meningoencephalitis (Pangandaheng, Mawuntu, \& Karema, 2017). The spread of disease through the blood triggers brain membrane inflammation. Therefore, it can cause uncontrolled movements and thoughts until the patient deceases (Elchirri, 2015). The prevention of Meningococcus Meningitis in high-risk groups is carried out by minimalizing contact between the patients and family members at home. A person exposed to oral secretions is treated with chemoprophylaxis antibiotics within 24 hours after the diagnosis is made. This disease is dangerous and contagious (Rustika et al., 2018).

The Port Health Office (PHO) is a technical implementation unit within the Ministry of Health of the Republic of Indonesia. The institution is under the auspices and shall have the responsibility to the Directorate General of
Disease Control and Environmental Health (DG DC-EH). The Port Health Office (PHO) has the authority to control the entry and exit of quarantine diseases and outbreaks of potentially infectious diseases. PHO performs limited health services, as well as controlling the impact of environmental health in the working area of the port/airport across the national borders. The prevention of the entry and exit of outbreaks of potentially infectious diseases are carried out by vaccinating all people who travel abroad (Mutiarani, 2018).

Indonesian pilgrims are vaccinated with Meningococcus Meningitis ACYW-135 vaccination to prevent the potential infectious meningitis outbreaks (Apriyandi, Adi, \& Widodo, 2017). Meningococcus Meningitis ACYW-135 vaccine injection is carried out at the Port Health Office or designated Government Hospital. The vaccination is mandatory for someone who will travel abroad. The dissolved vaccine is stored at 2$8{ }^{\circ} \mathrm{C}$ in an ice flask or refrigerator before it is injected. The vaccine cannot be used after 8 hours since the vaccine was dissolved, including the rest of the vaccine (Ministry of Health RI, 2017).

Meningococcus Meningitis ACYW-135 vaccine injection is carried out at the Port Health Office or designated Government Hospital. The 
vaccination is mandatory for someone who will travel abroad. The dissolved vaccine is stored at 2$8{ }^{\circ} \mathrm{C}$ in an ice flask or refrigerator before it is injected. The vaccine cannot be used after 8 hours since the vaccine was dissolved, including the rest of the vaccine (Lewaherilla, Maitimu, \& Niani, 2017).

The time-range of meningitis vaccination of less than 14 days can be overcome by groups who had meningitis vaccination as they have herd immunity. The level of resistance produced by $70 \%$ population will form herd immunity in this group (Mardiana, 2018). A large group immunity level will reduce the potential risk of someone who was vulnerable in contact with patients, thus enabling the cessation of disease transmission (Hikamarida, 2014).

Temperature and humidity in Middle Eastern countries such as Saudi Arabia are suitable for viruses and meningococcal bacteria. The viruses and meningococcal bacteria are developing rapidly at high and low temperatures, and it becomes a potential area of Meningococcus Meningitis endemic. In 2001, W135 serogroup Meningococcus Meningitis carriers were found in some of Hajj pilgrims from Indonesia. The incidence was probably related to the increasing cases of serogroup Meningococcus Meningitis similar to some other countries. The Meningococcus Meningitis outbreak that occurred in Saudi Arabia was classified in the W135 serogroup (64\%) and A serogroup (37\%). The world's first largest outbreak was caused by the W135 series (Hafshoh, Musthofa, \& Husodo, 2019).

The increasing number of pilgrims amount to 2 million people from 1,140 countries around the world in Mecca, resulting in an increasing infection potential risk. It causes meningitis to spread rapidly to pilgrims in multiple countries around the globe (Kholilurrahman, 2017). The bacterial transmission of Meningococcus Meningitis occurred over a long period. The interactions among thousands of people last for two weeks to one month in Mecca, which have the potential risk to increase meningitis cases. This is due to the high potential risk in contact in the endemic population area (Yitnaningrum, Sewu, \& Lucyati, 2015).

The increase in the number of Hajj and Umrah pilgrims from Indonesia has resulted in the requirement for special monitoring for Hajj and Umrah pilgrims. Follow-up is carried out during the Meningococcus Meningitis vaccination. Prevention of delayed vaccination aims to minimize the transmission of meningitis. The Meningococcus Meningitis vaccination is carried out at the Port Health Office (PHO) Class I of Surabaya, Tanjung Perak Port. This study aims to analyze the accuracy of the implementation of Meningococcus Meningitis vaccination in pilgrims at the PHO Class I of Surabaya, Tanjung Perak Port.

\section{METHODS}

The study employed descriptive quantitative research using a cross-sectional study design. The research samples were all 2,973 prospective Umrah pilgrims, vaccinated with Meningococcus Meningitis immunization. The variables consist of respondents, the respondents' sex, the respondents' domicile/residence, and the time-range between the implementation of Meningococcus Meningitis immunization.

Age, as variables, is classified into interval scales, i.e., children (2-11 years), early adolescence (12-16 years), late adolescents (17-25 years), early adulthood (26-35 years), late adulthood (36-45 year), early elderly (46-55 years), late elderly (56-65 years), and seniors (> 65 years). The domicile variable/residence was classified into two groups, i.e., Surabaya and Out of Surabaya. Vaccination variables time-range were calculated from the vaccination date to the departure date, and it was categorized as follows, i.e., less than 14 days and grreater than or equal to 14 days.

The study employed the secondary data that was obtained through monthly data recapitulation in the form of individual Umrah pilgrims' data and data recapitulation in the Port's Health Information System (SIMKESPEL) in December 2018. The data included the total population of Umrah pilgrims who took Meningococcus Meningitis vaccination in December 2018.

The collected data were grouped and analyzed univariably. The univariable analysis was displayed in descriptive form with frequency tables. Then, the data were interpreted and compared with the existing theories, standards, guidelines, and provisions. Besides, the problems must be identified, and alternative solutions must be acquired.

\section{RESULTS}

Umrah pilgrims who will carry out Umrah must take Meningococcus Meningitis vaccination in PHO Class I of Surabaya. Meningitis 
vaccination was carried out for the 2,973 pilgrims in the PHO Class I of Surabaya Tanjung Perak in December 2018.

\section{Distribution of Meningococcus Meningitis Vaccination Based on Demography}

The majority of Umrah pilgrims (24.62\%) got Meningococcus Meningitis immunization at the age range of 46 to 55 years old (Table 1). The majority of pilgrims were vaccinated in a period of more than or equal to 14 days before the departure. However, there were still pilgrims $(56.12 \%)$ who got vaccination at a period of less than 14 days who are mostly females (Table 2).

\section{Table 1}

The distribution of the implementation for Meningococcus Meningitis vaccination based on the age at PHO Class I of Surabaya, Tanjung Perak Port in December 2018

\begin{tabular}{lrr}
\hline \multicolumn{1}{r}{ Age (years) } & \multicolumn{1}{c}{$\mathrm{n}$} & \multicolumn{1}{c}{$\%$} \\
\hline $2-11$ & 89 & 2,99 \\
$12-16$ & 104 & 3,50 \\
$17-25$ & 298 & 10,02 \\
$26-35$ & 341 & 11,47 \\
$36-45$ & 508 & 17,09 \\
$46-55$ & 732 & 24,62 \\
$56-65$ & 569 & 19,14 \\
$>65$ & 332 & 11,17 \\
\hline Total & 2973 & 100,00 \\
\hline
\end{tabular}

\section{Distribution of Meningococcus Meningitis}

\section{Vaccination Based on Time-Range}

The majority of Umrah pilgrims in $\mathrm{PHO}$ Class I of Surabaya, Tanjung Perak Port in December 2018 got Meningococcus Meningitis vaccination for $>14$ days were $76 \% \quad(2,262$ pilgrims) (Figure 1). The majority of Umrah pilgrims who got vaccination within 5-6 days before the departure were $19.55 \%$ (139 pilgrims) (Figure 2).

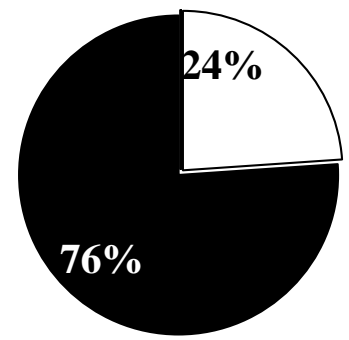

$\square$ vaccination range of $<14$ days prior to departure

- vaccination range of $>14$ days prior to departure

Figure 1. Time-Range Vaccination of Meningococcus Meningitis for Umrah Pilgrims in PHO Class I of Surabaya Tanjung Perak Port Work Area in December 2018

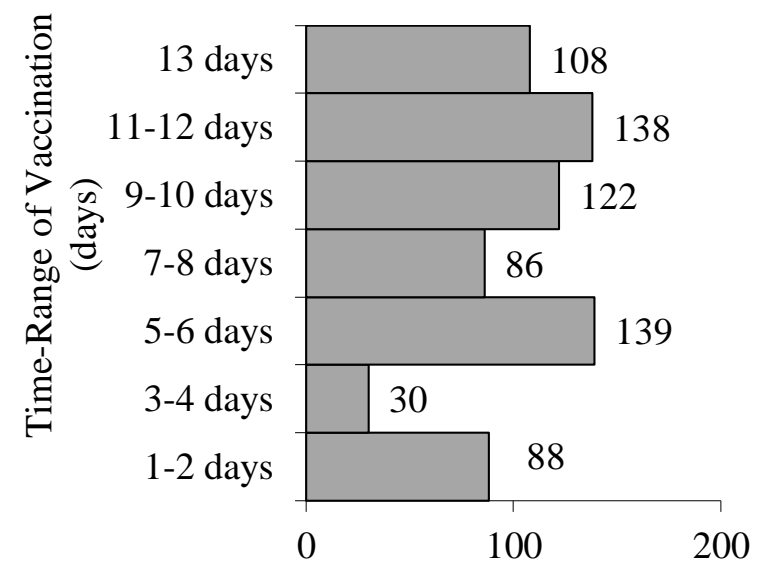

The amount of pilgrims (person)

Figure 2. Time-Range of Meningococcus Meningitis Vaccination less than 14 days for Umrah pilgrims in PHO Class I of Surabaya, Tanjung Perak Port in December 2018.

\section{Distribution of Meningococcus Meningitis Vaccination Based on Residence \\ The majority of Umrah pilgrims who carried out Meningococcus Meningitis vaccination in the range of less than 14 days in PHO Class I of Surabaya Tanjung Perak Port came from Surabaya were $55.27 \%$ (393 pilgrims) (Table 2).}

\section{DISCUSSION}

Meningococcus Meningitis becomes a major concern in the Hajj and Umrah implementation . This disease is caused by bacterium Neisseria meningitidis which attacks the human brain membrane. The cases of meningitis occur at \pm 3 from 100,000 people in range from all ages from infants to elderly. WHO data stated that the disease has resulted 530 deaths from Meningococcus Meningitis in 5,300 people in Burkina Faso in 2012. The endemic area of Meningococcus Meningitis is called as the "Meningitis Belt" (Hoesea, 2014).

The epidemiological determinant of meningitis in Umrah pilgrims consists of hosts, agent, and environment. Male host has twice larger risk than female host in Meningococcus Meningitis incidence. The agent of meningitis that occur on Umrah/Hajj pilgrims is Meningococcus Meningitis serogroups W 135. The spread of Meningococcus Meningitis in Hajj and Umrah pilgrims increases in conditions where the environment is crowded with residents, i.e., boarding house, soldiers' barracks, and pilgrims dormitories (Simanullang, Sarumpaet, \& Rasmaliah, 2015). 
Table 2

Distribution of Time-Range of Meningococcus Meningitis Vaccination Based on Gender and Residence

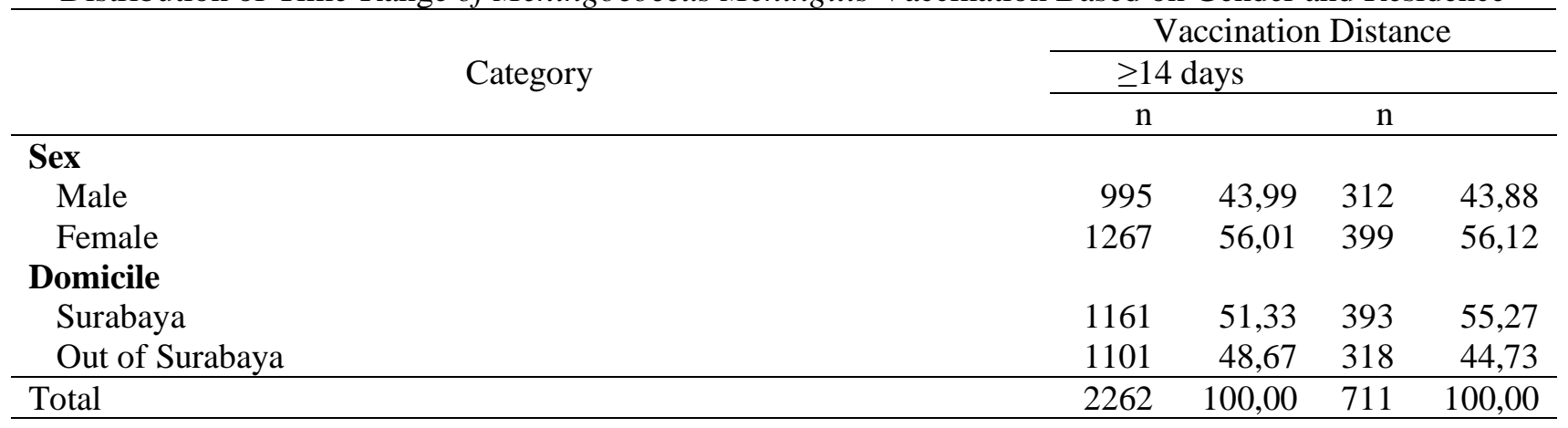

The meningitis frequency distribution was categorized into three aspects, such as people, places, and times. Frequency distribution based on people was influenced by age, gender, and immunity. Meningococcus Meningitis disease commonly occurs in men than in women. The frequency distribution based on the place was the potential transmission risk of meningitis generally occurs in crowded neighborhood, such as boarding houses, soldiers' barracks, and pilgrims' dormitories. The frequency distribution of meningitis based on the time that the disease has highly spread during the summer when the respiratory tract infections increase (Simanullang et al., 2015).

The Port Health Office Class I of Surabaya has some duties including potential outbreaks prevention, quarantine, health services, and facilitation and advocacy for outbreaks prevention and health disasters including meningitis (Yusri, Imran, \& Mudatsir, 2016). Some of the precautions that can be performed in people who are in the endemic area of the high potential risk of contagious diseases are by performing immunization and chemoprophylaxis (Yitnaningrum et al., 2015).

The ACYW-135 Meningococcus Meningitis vaccination is carried out at the Port Health Office (PHO) or Government Hospital compulsorily for someone who will travel abroad. Vaccination is carried out in a range of a minimum of 1 month before the departure (Rustika et al., 2018).

\section{Distribution of Meningococcus Meningitis Vaccination Based on People's Aspects}

The majority of Meningococcus Meningitis vaccination in PHO Class I of Surabaya in Tanjung Perak Port in December 2018 was carried out for early elderly category. Female pilgrims served as the majority who were vaccinated with meningococcus meningitis immunization in less than 14 days.

The meningococcus meningitis vaccination in the PHO Class I of Surabaya, Tanjung Perak Port that are injected in a range of less than 14 days have a high potential risk of transmission. The more pilgrims go to the Mecca to perform Umrah, the higher the risk of transmission as there are so many people who come from various countries. The Meningococcus Meningitis cases are never found in Indonesia so far because the herd immunity eas taken from standard procedure of vaccination which was carried out more than or equal to 14 days before departure. One of the potentially high risk groups to be infected by the diseases is pregnant women (Jayanti, 2017).

\section{Distribution of Meningococcus Meningitis Vaccination Based on Time-Range}

In 2010-2013, there were no Indonesian pilgrims identified with suspected meningitis and contagious diseases, and the potential of other outbreaks after performing Hajj and Umrah. The promptly immunization of Menveo ACWY vaccine serve as effective and safe actions to prevent Meningococcus Meningitis disease and other potential disease outbreaks (Lewaherilla et al., 2017).

Most Meningococcus Meningitis vaccination in PHO Class I of Surabaya, Tanjung Perak Port are injected more than or equal to 14 days before departure of Hajj and Umrah. Umrah pilgrims amounted to $24 \%$ (711 pilgrims) were vaccinated in less than 14 days, while the others amounted to $19.55 \%$ (139 pilgrims) were vaccinated at 5-6 days before the departure. PHO Class I of Surabaya issued a circular based on the provisions of the amendment to article 8 through Minister of Health Regulation Number 12, 2019 concerning the service and publication of the International Vaccination Certificate (ICV). The circular letter 
explains that the vaccination must be carried out at least ten days before the departure; otherwise, the departure will be delayed. The policy will take effect on June 1, 2019 (Ministry of Health RI, 2019).

The policy aims to tighten the monitoring vaccination at PHO Class I of Surabaya. Disease monitoring trend is also carried out by providing information in planning disease prevention measurement and health services. The disease transmission prevention is an important part of the Early Awareness System (EAS) which cannot be separated from the implementation of a surveillance system (Hoesea, 2014).

The interview results of pilgrims who got vaccination stated that the pilgrims did not understand about the minimum standard for vaccination, and they submitted all requirements to the travel agent. The pilgrim were vaccinated based on directions from travel agent, so there were still pilgrims that got a vaccination in less than 14 days. The Meningococcus Meningitis efficacy vaccine is $95 \%$ and it has an effective immune protection for two years. Pilgrims antibodies are formed in 10-14 days after vaccination. The re-vaccination of meningitis can be performed after two years since the previous one (Ministry of Health RI, 2017).

The interview results of pilgrims who got vaccination stated that the pilgrims did not understand about the minimum standard for vaccination, and they submitted all requirements to the travel agent. The pilgrim were vaccinated based on directions from travel agent, so there were still pilgrims that got a vaccination in less than 14 days. The Meningococcus Meningitis efficacy vaccine is $95 \%$ and it has an effective immune protection for two years. Pilgrims antibodies are formed in 10-14 days after vaccination. The re-vaccination of meningitis can be performed after two years since the previous one (Tiani, Bakhtiar, \& Usman, 2016).

The vaccination of Meningococcus Meningitis, if carried out less than 14 days, will result in a not fully formed immune system. The implementation of Meningococcus Meningitis vaccination in less than 14 days was covered by the pilgrims who are already vaccinated more than or equal to 14 days due to injection that have properties of herd Immunity (Hikamarida, 2014).

The cases of meningitis in both Hajj and Umrah pilgrims had yet to be found although some pilgrims had been vaccinated less than 14 days in PHO Class I of Tanjung Perak Port Work Area. This is because the nature of vaccination was herd immunity or group immunity. The immunity of the pilgrims that had antibodies also helps protect other pilgrims who are vaccinated less than 14 days before the departure (Nirmala \& Harlina, 2017).

\section{Distribution of Meningococcus Meningitis Vaccination Based on Residence}

The vaccine administration in PHO Class I of Surabaya Tanjung Perak Port Work Area is under the established ACWY vaccine standards. Meningococcus Meningitis vaccine was also given as one of the conditions for obtaining a visa with the proven ICV (International Certificate Vaccination) (Dani, 2018).

In carrying out the vaccination of Meningococcus Meningitis in PHO Class I of Surabaya Tanjung Perak Port Work Area, 711 pilgrims $(24 \%)$ were found to carry out vaccinations less than 14 days. The majority of those pilgrims were from Surabaya. That was because the majority of prospective pilgrims from Surabaya got the vaccination in the local area that was easily accessible, namely PHO Class I of Surabaya and vice versa. This situation does not exclude the possibility that the implementation of meningitis vaccination in less than 14 days are also found in other cities. This situation occurs because the pilgrims got the vaccination individually although the socialization of minimum standards for vaccination had been done. Besides being carried out at Port Health Office (PHO), the implementation of Meningococcus Meningitis vaccination can also be carried out at the Government Hospital (Ministry of Health RI, 2017). In carrying out the vaccination of Meningococcus Meningitis in PHO Class I of Surabaya Tanjung Perak Port Work Area, 711 pilgrims (24\%) were found to carry out vaccinations less than 14 days. The majority of those pilgrims were from Surabaya. That was because the majority of prospective pilgrims from Surabaya got the vaccination in the local area that was easily accessible, namely PHO Class I of Surabaya and vice versa. This situation does not exclude the possibility that the implementation of meningitis vaccination in less than 14 days are also found in other cities. This situation occurs because the pilgrims got the vaccination individually although the socialization of minimum standards for vaccination had been done. Besides being carried out at Port Health Office (PHO), the implementation of Meningococcus Meningitis vaccination can also be carried out at the 
Government Hospital (Ministry of Health RI, 2019).

The prevention of carrying out Meningococcus Meningitis vaccination less than 14 days can be done by disseminating information to travel agents throughout East Java. Based on the interviews conducted by the researchers, most of the prospective Umrah pilgrims who got vaccinated less than 14 days prior to departure trusted to travel agents to arrange all requirements in departure preparation, including scheduling vaccinations. Therefore, travel agents and government parties, especially $\mathrm{PHO}$, need to work together in scheduling prospective Umrah pilgrims' immunizations.

\section{CONCLUSIONS}

The majority of Meningococcus Meningitis vaccination in PHO Class I of Tanjung Perak Port Work Area, Surabaya in December 2018 was carried out on time. However, there were still prospective pilgrims who were not on time to get the vaccination $(<14$ days). The majority of vaccination activities in the category of less than 14 days were carried out in the range of 5-6 days before the departure. Most of the prospective Umrah pilgrims trusted their travel agents in scheduling vaccinations. Therefore, travel services and government parties, especially PHO, need to work together in scheduling prospective Umrah pilgrims' immunizations.

\section{ACKNOWLEDGEMENT}

The authors would like to express their gratitude towards the Chief of Port Health Office Class I Surabaya, Head of CQES (Control Quarantine and Epidemiological Surveillance), and supervisor field, along with the staff who have given the permission and guidance for the implementation of the internship and research in Port Health Office Class I of Surabaya, Tanjung Perak Port Work Area.

\section{REFERENCES}

Apriyandi, D., Adi, K., \& Widodo, A. P. (2017). Design of web-based meningitis vaccination administration information system at Banda Aceh Port Health Office Class III. Jurnal Manajemen Kesehatan Indonesia, 5(2), 131137.

Dani, A. A. (2018). Problems with managing the management of umrah in the Surakarta City.
Ilmu Dakwah: Academic Journal for Homiletic Studies, 12(1), 23-45. https://doi.org/10.15575/idajhs.v12i.1903

Elchirri, N. (2015). Contemporary issues regarding meningitis vaccination. Analytica Islamica, 4(2), 377-395.

Hafshoh, S. O., Musthofa, S. B., \& Husodo, B. T. (2019). Several factors related to the acceptance of umrah pilgrims to the meningitis vaccine at the Class II Port Health Office Semarang. Jurnal Kesehatan Masyarakat (e-Journal), 7(1), 527-534.

Hikamarida, F. (2014). The closeness of storage and recording with the quality of the DPT vaccine cold chain in the community health centers (puskesmas). Jurnal Berkala Epidemiologi, 2(3), 380-391.

Hoesea, E. V. (2014). Evaluation of health surveillance activities of hajj 2013 embarkation Palangkaraya. Jurnal Berkala Epidemiologi, 2(2), 206-215.

Jayanti, K. D. (2017). Implementation of the pilgrimage health surveillance system at the Surabaya City Health Office. Jurnal Ilmu Kesehatan Masyarakat, 13(2), 103-116. https://doi.org/10.19184/ikesma.v13i2.7031

Ministry of Health RI. (2017). Regulation of the Minister of Health of the Republic of Indonesia number 12 of 2017 concerning the implementation of immunization. Jakarta: Ministry of Health RI.

Ministry of Health RI. (2019). Minister of Health RI Regulation No. 12 of 2019 concerning amendment to minister of health regulation No. 23 of 2018 concerning Services and international vaccination certificate issuance. Jakarta: Ministry of Health RI.

Kholilurrahman. (2017). The elderly's hajj is reviewed from the perspective of Islamic guidance and counseling. Al-Balagh: Jurnal Dakwah dan Komunikasi, 2(2), 231-241. https://doi.org/10.22515/balagh.v2i2.1021

Lewaherilla, N., Maitimu, F. A. A. P., \& Niani, C. R. (2017). Model of the spread of meningitis in the Hajj season in Medina and Mecca. Jurnal Ilmu Matematika dan Terapan, 11(1), $55-62$.

Mardiana, D. E. (2018). The Influence of immunization and population density to diphtheria's prevalence in East Java. Jurnal Berkala Epidemiologi, 6(2), 122. https://doi.org/10.20473/jbe.v6i22018.122129

Mutiarani, P. T. (2018). Study of cargo vessel sanitation and the presence E.Coli bacteria on 
food in the Port Area of Tanjung Perak Surabaya. Jurnal Kesehatan Lingkungan, 9(2), 111-121. https://doi.org/10.20473/jkl.v9i2.2017.11121

Nirmala, F. F., \& Harlina, T. (2017). The perception of Islamic organizations members in the Maluku region on meningitis immunization / vaccination and biology studies. Jurnal Biology Science \& Education, 6(1), 69-83.

Pangandaheng, E. A. S. S., Mawuntu, A. H. ., \& Karema, W. (2017). Description of the level of knowledge and behavior of people about meningitis in Soataloara II Village, Tahuna District, Sangihe Islands Regency. Jurnal ECliniC, 5(2), 114-121.

Rustika, R., Puspasari, H. W., \& Kusnali, A. (2018). Policy analysis of the Umrah pilgrimage meningitis vaccination service in Indonesia. Buletin Penelitian Sistem Kesehatan, 21(1), 60-70. https://doi.org/10.22435/hsr.v21i1.96

Simanullang, R., Sarumpaet, S. M., \& Rasmaliah. (2015). Characteristics of child meningitis sufferers who are hospitalized at the Santa Elisabeth Hospital Medan in 2010-2014. Gizi, Kesehatan Reproduksi dan Epidemiologi, 1(4), 1-10.

Tiani, I., Bakhtiar, \& Usman, S. (2016). The role of immunization officers in administering pentavalent vaccinations. Jurnal Ilmu Keperawatan, 4(1), 83-98.

Yitnaningrum, Y., Sewu, L. S., \& Lucyati, A. (2015). Juridical review of the obligation to implement preventive measures and meningitis thickening for prospective Indonesian workers in Saudi Arabia related to the principle of safety. SOEPRA Jurnal Hukum Kesehatan, 1(1), 116-128.

Yusri, Imran, \& Mudatsir. (2016). Analysis of Banda Aceh Port III Class Health Office preparedness to face the risk of the Mers$\mathrm{CoV}$ virus infection at Sultan Iskandar Muda Airport in 2015. Jurnal Kedokteran Syiah Kuala, 16(2), 93-98. 